\title{
Ethanolic Neem (Azadirachta indica) Leaf Extract Prevents Growth of MCF-7 and HeLa Cells and Potentiates the Therapeutic Index of Cisplatin
}

\author{
Chhavi Sharma, ${ }^{1}$ Andrea J. Vas, ${ }^{1}$ Payal Goala, ${ }^{1}$ Taher M. Gheewala, ${ }^{1}$ \\ Tahir A. Rizvi, ${ }^{2}$ and Arif Hussain ${ }^{1}$ \\ ${ }^{1}$ Department of Biotechnology, Manipal University, Dubai International Academic City, P.O. Box 345050, Dubai, UAE \\ ${ }^{2}$ Department of Microbiology and Immunology, Faculty of Medicine and Health Science, UAE University, P.O. Box 17666, Al Ain, UAE
}

Correspondence should be addressed to Arif Hussain; dr.arifhussain@yahoo.co.in

Received 5 September 2013; Revised 13 November 2013; Accepted 15 November 2013; Published 30 January 2014

Academic Editor: Akira Hara

Copyright (c) 2014 Chhavi Sharma et al. This is an open access article distributed under the Creative Commons Attribution License, which permits unrestricted use, distribution, and reproduction in any medium, provided the original work is properly cited.

\begin{abstract}
The present study was designed to gain insight into the antiproliferative activity of ethanolic neem leaves extract (ENLE) alone or in combination with cisplatin by cell viability assay on human breast (MCF-7) and cervical (HeLa) cancer cells. Nuclear morphological examination and cell cycle analysis were performed to determine the mode of cell death. Further, to identify its molecular targets, the expression of genes involved in apoptosis, cell cycle progression, and drug metabolism was analyzed by RT-PCR. Treatment of MCF-7, HeLa, and normal cells with ENLE differentially suppressed the growth of cancer cells in a dose- and time-dependent manner through apoptosis. Additionally, lower dose combinations of ENLE with cisplatin resulted in synergistic growth inhibition of these cells compared to the individual drugs (combination index $<1$ ). ENLE significantly modulated the expression of bax, cyclin D1, and cytochrome P450 monooxygenases (CYP 1A1 and CYP 1A2) in a time-dependent manner in these cells. Conclusively, these results emphasize the chemopreventive ability of neem alone or in combination with chemotherapeutic treatment to reduce the cytotoxic effects on normal cells, while potentiating their efficacy at lower doses. Thus, neem may be a prospective therapeutic agent to combat gynecological cancers.
\end{abstract}

\section{Introduction}

Therapeutic properties of neem (Azadirachta indica) have been recognized since ancient times and have been extensively used in ayurveda, unani, and homoeopathic medicine [1]. Many compounds such as limonoids, azadirone, azadirachtin, and flavonoids, having therapeutic potential, have been isolated from various parts of neem tree and have been evaluated for their pharmacological actions and plausible medicinal applications along with their safety evaluation. Recent studies have shown that neem possesses anti-inflammatory, antiarthritic, antipyretic, hypoglycemic, antigastric ulcer, antifungal, antibacterial, and antitumor activities [2-6].

The antineoplastic properties of neem are gaining attention due to its cancer preventive, tumor-suppressive, antiproliferative, apoptosis-inducing, antiangiogenic, and immunomodulatory effects via several molecular mechanisms $[6,7]$. Neem or its derivatives have been shown to exert their antioxidant properties by decreasing TNF- $\alpha$, increasing IFN- $\gamma$, and modulating antioxidant enzymes such as glutathione S-transferase (GST) and certain hepatic cytochrome P450-dependent monooxygenases [7-13]. It induces apoptosis via both the intrinsic and extrinsic pathways and induces cell cycle arrest via p53-dependent p21 accumulation and downregulation of the cell cycle regulatory proteins cyclin $\mathrm{B}$, cyclin D1, p53, and proliferating cell nuclear antigen (PCNA) [11, 14-16]. Interestingly, when used in conjunction with chemotherapeutic drugs like cyclophosphamide, cisplatin, 5-fluorouracil, or with radiotherapy, it potentiates their antitumor effects by activating proapoptotic signaling and negating survival signaling along with attenuating their side effects [14, 17-20]. Notably, cisplatin, the first member of a class of platinum-containing anticancer drugs, is widely used for treatment of solid malignancies. Cisplatin has a number of side-effects that can limit its use: nephrotoxicity, nausea and vomiting, ototoxicity (hearing loss), electrolyte 
disturbance, and hemolytic anemia, etc. Also, the majority of cancer patients eventually develop cisplatin-resistant disease necessitating combination therapy approach using multiple chemotherapeutic agents or combining with chemopreventive agents $[21,22]$.

Based on the facts mentioned above, the present study aims to evaluate the chemopreventive potential of ethanolic neem leaves extract (ENLE) alone or concurrently with cisplatin on human breast (MCF-7) and cervical (HeLa) cancer cells, with the objective of studying its antiproliferative activity on cancer cells while decreasing the cytotoxic effects on normal cells. Also, the molecular targets of ENLE were delineated to elucidate its in vitro anticancer effects.

\section{Material and Methods}

2.1. Cell Culture. The human breast cancer cell line, MCF-7, and human cervical carcinoma cell line, HeLa were maintained in DMEM (Sigma, USA) supplemented with 10\% fetal bovine serum (FBS) (Sigma, USA) and 100x Pen-strep (Sigma, USA) in a humidified atmosphere of $5 \% \mathrm{CO}_{2}$ in air at $37^{\circ} \mathrm{C}$. Lymphocytes were isolated from healthy nonsmoking donors using HiSep Media (HiMedia, India) as per the manufacturer's instructions [23] and were maintained in RPMI media (Sigma, USA).

2.2. Preparation of Drug Solutions. 5\% ethanolic neem leaves extract (ENLE) was prepared as described previously by Subapriya and coworkers (2005) with slight modifications [24]. Briefly, $2.5 \mathrm{~g}$ of fresh mature neem leaves was ground to a fine paste in $50 \mathrm{~mL}$ of $100 \%$ ethanol and the slurry was air-dried in a shaking incubator at $37^{\circ} \mathrm{C}$ with intermittently stirring at $2 \mathrm{~h}$ and then left overnight. The powder obtained was weighed and resuspended in dimethyl sulphoxide (DMSO) (Sigma, USA) to prepare a stock solution of $80 \mathrm{mg} / \mathrm{mL}$ which was filtered through $0.2 \mu \mathrm{m}$ filter. Further dilutions were prepared in DMEM to require concentrations between 10 and $500 \mu \mathrm{g} / \mathrm{mL}$ for treatment of MCF-7 cells, HeLa cells, and lymphocytes.

A stock solution of $3.3 \mathrm{mM}$ of cisplatin (Cadila Pharmaceuticals Ltd., India) was used to make drug dilutions of varying concentrations $(1-200 \mu \mathrm{M})$ in complete medium.

2.3. Cell Viability Assay. The effect of ENLE and its combination with cisplatin, a chemotherapeutic agent, on the viability of MCF-7, HeLa, and lymphocytes was determined by 3[4,5-dimethylthiazol-2-yl]-2,5-diphenyl tetrazoliumbromide (MTT) assay. The cells were plated in triplicate at a density of $\sim 1 \times 10^{4}$ cells/well in $200 \mu \mathrm{L}$ of complete culture medium containing $10-500 \mu \mathrm{g} / \mathrm{mL}$ concentrations of ENLE alone for 48 and $72 \mathrm{~h}$ and 24 and $48 \mathrm{~h}$ for MCF-7 and HeLa, respectively, or a combination of ENLE (N1M and N2M $=50$ and $100 \mu \mathrm{g} / \mathrm{mL}$; $\mathrm{N} 1 \mathrm{H}$ and $\mathrm{N} 2 \mathrm{H}=10$ and $50 \mu \mathrm{g} / \mathrm{mL}$ ) with cisplatin (C1M and $\mathrm{C} 2 \mathrm{M}=1$ and $10 \mu \mathrm{M}$ in MCF-7; $\mathrm{C} 1 \mathrm{H}$ and $\mathrm{C} 2 \mathrm{H}=1$ and $5 \mu \mathrm{M}$ ) for 48 and $24 \mathrm{~h}$, respectively, for MCF-7 and HeLa in 96well microtiter plates. After incubation for specified times at $37^{\circ} \mathrm{C}$ in a humidified incubator, MTT $(5 \mathrm{mg} / \mathrm{mL}$ in PBS) was added to each well and incubated for $2 \mathrm{~h}$. The absorbance was recorded on a microplate reader at the wavelength of
$570 \mathrm{~nm}$ [23]. The effect of ENLE on growth inhibition was assessed as percent cell viability and was calculated as (OD of the drug-treated sample/OD of the nontreated sample) $\times 100$, considering that the colorimetric signal is directly proportional to the number of viable cells. The $\mathrm{EC}_{50}(50 \%$ effective concentration) values were calculated from the doseresponse curves.

2.4. Calculation of Combination Effects of Cisplatin and ENLE. Calculations of combination effects were expressed as a combination index (CI) as described previously [23]. CI analysis provides qualitative information on the nature of drug interaction, and CI, a numerical value, was calculated according to the following equation:

$$
\mathrm{CI}=\frac{\mathrm{C}_{\mathrm{A}, x}}{\mathrm{IC}_{x, \mathrm{~A}}}+\frac{\mathrm{C}_{\mathrm{B}, x}}{\mathrm{IC}_{x, \mathrm{~B}}},
$$

where $C_{A, x}$ and $C_{B, x}$ are, respectively, the concentrations of drugs $\mathrm{A}$ and $\mathrm{B}$ used in combination to achieve $x \%$ drug effect. $\mathrm{IC}_{x, \mathrm{~A}}$ and $\mathrm{IC}_{x, \mathrm{~B}}$ are the concentrations for single agents to achieve the same effect. A CI value $<1,=1$, or $>1$ represents, respectively, synergy, additivity, or antagonism of cisplatin and ENLE, respectively.

\subsection{Detection of Apoptosis in MCF-7 and HeLa Cells after Treatment with ENLE}

2.5.1. Microscopic Examination. Morphological changes of MCF-7and HeLa cells were noted on treatment with ENLE at different concentrations $(50,200$, and $500 \mu \mathrm{g} / \mathrm{mL})$ and time-points (48 and $72 \mathrm{~h}$ for MCF-7 and 24 and $48 \mathrm{~h}$ for HeLa) using normal inverted microscope (Labomed, USA) (Figures 2(a) and 2(b)). The untreated cells were used as negative control.

2.5.2. Nuclear Morphological Studies. Apoptosis induction after treatment of MCF-7 and HeLa cells with ENLE at their respective $\mathrm{EC}_{50}$ concentrations and varying time-points $(350 \mu \mathrm{g} / \mathrm{mL}$ for 0,48 , and $72 \mathrm{~h}$ in MCF-7 and $175 \mu \mathrm{g} / \mathrm{mL}$ for 0 , 24 , and $48 \mathrm{~h}$ in HeLa cells) was evaluated by the nuclear morphological changes associated with it using propidium iodide staining (Figures 3(a) and 3(b)) [22]. Briefly, $\sim 10^{6}$ cells $/ \mathrm{mL}$ cells were seeded on glass coverslips and incubated overnight in complete medium at $37^{\circ} \mathrm{C}$. Further, cells were treated with ENLE at its $\mathrm{EC}_{50}$ for above mentioned time periods. At the end of the desired time interval, cells were fixed in a mixture of acetone: methanol $(1: 1)$ at $-20^{\circ} \mathrm{C}$ for $10 \mathrm{~min}$, washed with 1X PBS ( $\mathrm{pH} 7.4$ ) twice, and stained with propidium iodide (10 mg/mL in PBS) for $30 \mathrm{~s}$ in dark at RT. The coverslips were thoroughly washed with PBS and placed upturned onto a glass slide with mounting media (DPX). Slides were viewed at $515 \mathrm{~nm}$ under the Progress Fluorescent Microscope (Olympus, USA). The images were captured at $40 \mathrm{x}$ magnification.

2.5.3. Quantification of Apoptotic Cells by Flow Cytometry. Cell cycle analysis of ENLE-treated MCF-7 and HeLa cells was performed by flow cytometry as described earlier (Figure 4) [23]. After treatment of synchronous cultures of 


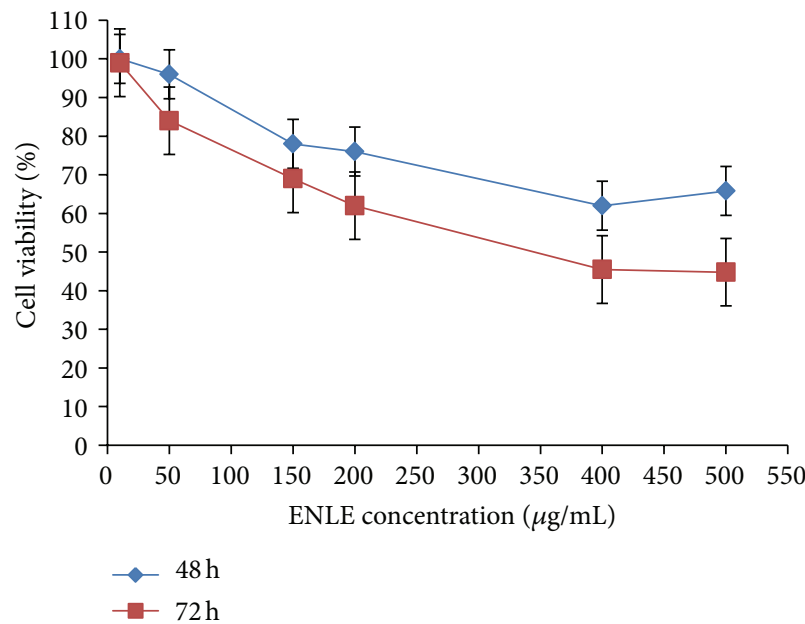

(a)

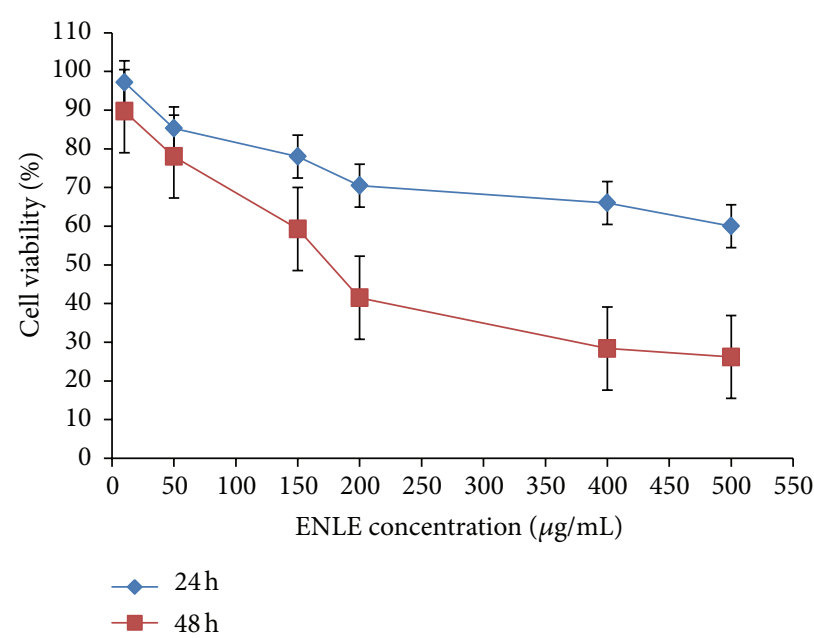

(b)

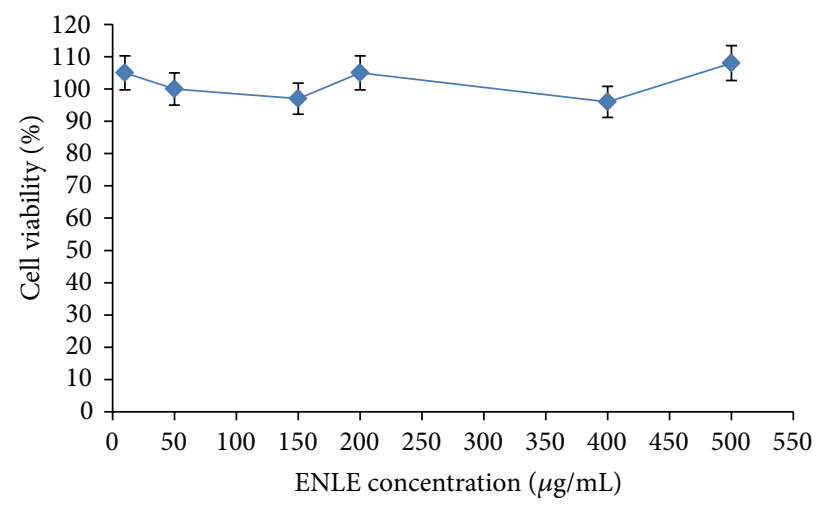

(c)

FIGURE 1: Differential cytotoxic effect of ENLE on MCF-7, HeLa, and lymphocytes. (a, b) MCF-7 and HeLa cells treated with ENLE at varying concentrations $(10-500 \mu \mathrm{g} / \mathrm{mL})$, resulting in dose- and time-dependent growth inhibition. The $\mathrm{EC}_{50}$ for MCF-7 and HeLa cells was found to be $350 \mu \mathrm{g} / \mathrm{mL}$ at $72 \mathrm{~h}$ and $175 \mu \mathrm{g} / \mathrm{mL}$ at $48 \mathrm{~h}$, respectively. However, lymphocytes did not show significant growth inhibition when treated with similar concentrations of ENLE for $24 \mathrm{~h}(\mathrm{c})$. Values are means + SD of three independent experiments. Each value with ENLE treatment differs from the control value $(P<0.05)$.

MCF-7 and HeLa cells with ENLE at their respective $\mathrm{EC}_{50}$ concentrations at various time-points $(350 \mu \mathrm{g} / \mathrm{mL}$ for 0,48 , and $72 \mathrm{~h}$ in MCF-7 and $175 \mu \mathrm{g} / \mathrm{mL}$ for 0,24 , and $48 \mathrm{~h}$ in HeLa cells), both adherent and floating cells were harvested, washed with phosphate buffered saline (PBS, pH 7.2), and fixed with ice-cold absolute ethanol at $-20^{\circ} \mathrm{C}$ overnight. Cells were then washed with PBS prior to resuspending in a buffer containing PI $(50 \mathrm{mg} / \mathrm{mL}), 0.1 \%$ sodium citrate, $0.1 \%$ Triton $\mathrm{X}-100$, and $100 \mathrm{mg} / \mathrm{mL}$ of RNase A. The cells were analyzed using Flow cytometry (Beckman Coulter flow Cytometer FC500, CXP Version 2.2). The data was analyzed using the Beckman Coulter KALUZA 1.1 analysis software.

2.6. Expression Analysis of Various Genes Targeted by ENLE. Reverse transcription PCR was used to detect the expression of Bax, cyclin D1, CYP 1A1, and CYP 1A2 in response to treatment with ENLE at $\mathrm{EC}_{50}$ for varying time intervals $(350 \mu \mathrm{g} / \mathrm{mL}$ for 0,48 , and $72 \mathrm{~h}$ in MCF-7 and $175 \mu \mathrm{g} / \mathrm{mL}$ for 0, 24, and $48 \mathrm{~h}$ in HeLa cells) (Figures 5(a) and 5(b)). Total RNA extraction from untreated and ENLE-treated MCF-7 and HeLa cells was carried out as per the manufacturer's instructions (GenElute Mammalian Genomic Total RNA Kit, Sigma, USA) at various time intervals. Further, total RNA was subjected to first strand synthesis as per manufacturer's protocol (ProtoScript M-MuLV Taq RT-PCR Kit, New England Biolabs, USA) followed by PCR using gene-specific primers $[23,25-28]$. $\beta$-Actin was taken as an internal control. The PCR cycle was as follows: initial denaturation at $95^{\circ} \mathrm{C}$ for $5 \mathrm{~min}$, followed by 35 amplification cycles (denaturation at $94^{\circ} \mathrm{C}$ for $30 \mathrm{~s}$; annealing at $55^{\circ} \mathrm{C}$ for $\beta$-actin, CYP $1 \mathrm{~A} 1$, and CYP $1 \mathrm{~A} 2,56^{\circ} \mathrm{C}$ for Bax, and $54^{\circ} \mathrm{C}$ for cyclin $\mathrm{D} 1$; and extension at $72^{\circ} \mathrm{C}$ for $45 \mathrm{~s}$ ), with final extension at $72^{\circ} \mathrm{C}$ for $7 \mathrm{~min}$. Amplified products were visualized on a $2 \%$ agarose gel containing ethidium bromide.

\section{Statistical Analysis}

All data are expressed as means \pm SD of at least 3 experiments. Fisher's exact test was adopted for statistical evaluation of the results. Significant differences were established at $P<0.05$. 
$48 \mathrm{~h}$
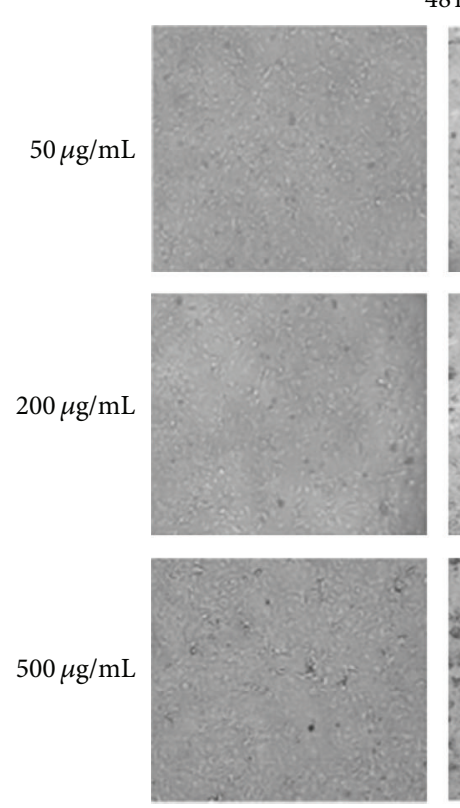

(a)

$24 \mathrm{~h}$
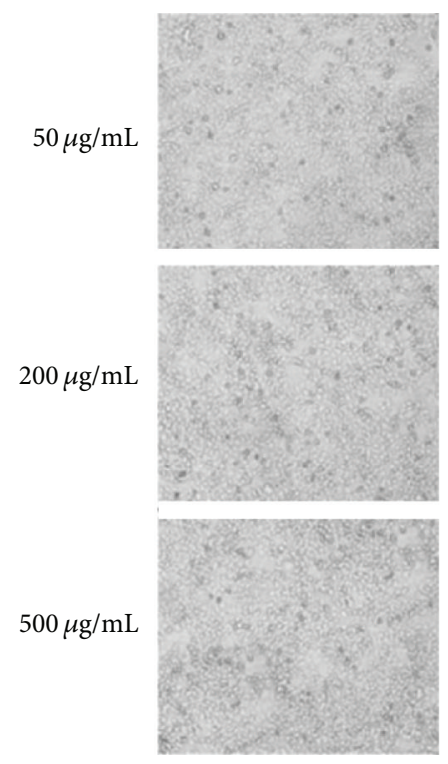
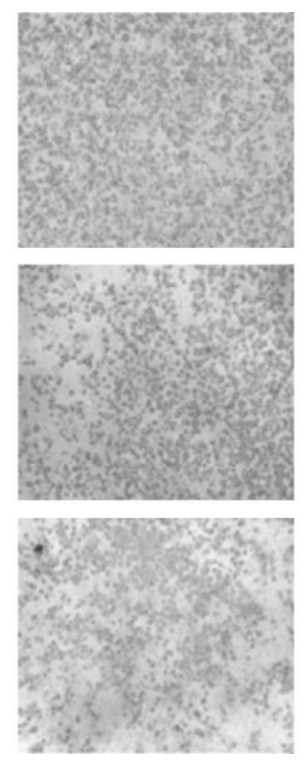
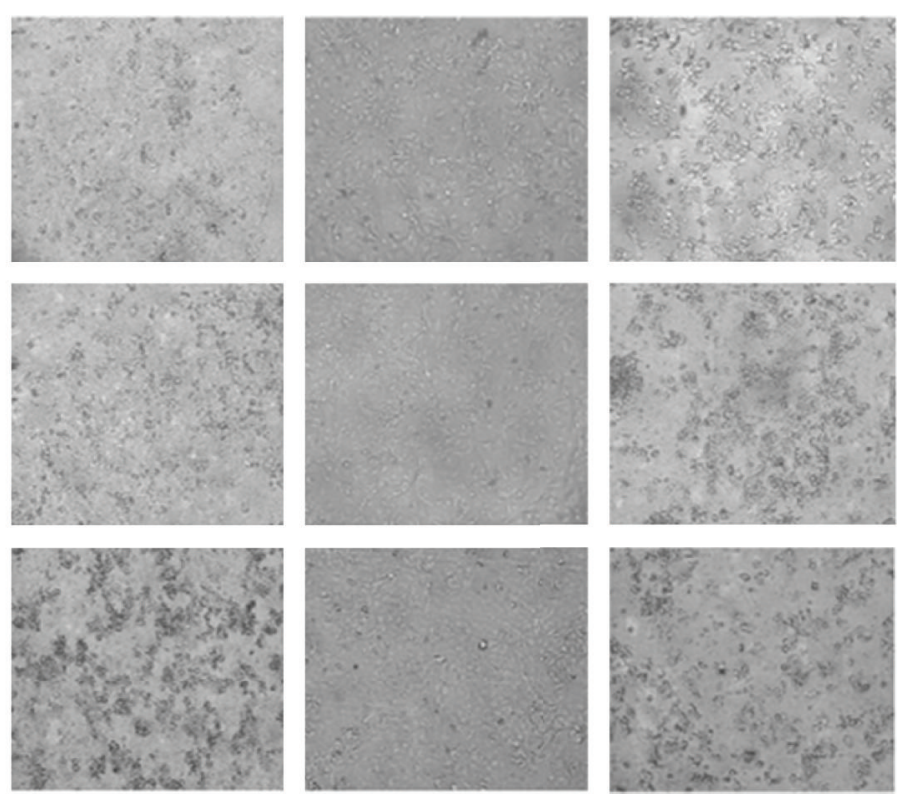

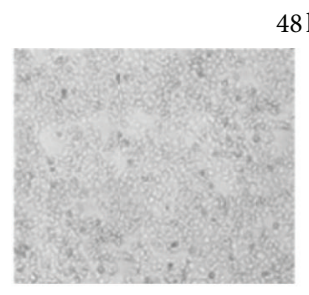

$48 \mathrm{~h}$
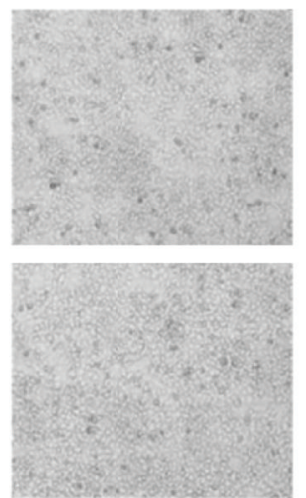
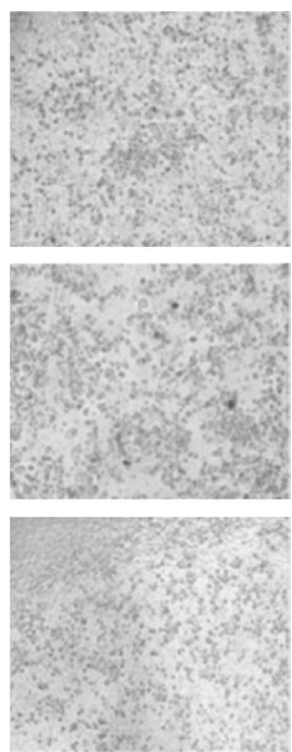

(b)

FIGURE 2: ENLE-induced morphological changes in MCF-7 (a) and HeLa cells (b) at varying concentrations and time-points. 50, 200, and $500 \mu \mathrm{g} / \mathrm{mL}$ ENLE-treated (a) MCF-7 (for 48 and $72 \mathrm{~h}$ ) and (b) HeLa cells (24 and $48 \mathrm{~h}$ ) showed dose- and time-dependent increase in the morphological changes associated with cell death via apoptosis compared to the untreated cells (magnification 100x).

\section{Results}

4.1. ENLE Shows Selective Cytotoxic Effects towards MCF7 and HeLa Cells. The antiproliferative effects of different concentrations of ENLE on MCF-7 cells, HeLa cells, and lymphocytes were evaluated by the MTT assay. MCF-7 and HeLa cells treated with increasing concentrations of ENLE ranging from 10 to $500 \mu \mathrm{g} / \mathrm{mL}$ showed a dose- and timedependent increase in cell death (Figures 1(a) and 1(b)). In
MCF-7 cells, the $\mathrm{EC}_{50}$ was observed at $350 \mu \mathrm{g} / \mathrm{mL}$ after $72 \mathrm{~h}$ treatment with ENLE, whereas in HeLa cells, it was found to be $175 \mu \mathrm{g} / \mathrm{mL}$ in $48 \mathrm{~h}$ (Figures 1(a) and 1(b)).

Notably, to assess if ENLE possesses a safe cytotoxic profile, MTT assay was performed on lymphocytes isolated from a healthy nonsmoker adult at similar doses of ENLE (10$500 \mu \mathrm{g} / \mathrm{mL}$ ) (Figure 1(c)). No significant effect on cell viability was observed after treatment with ENLE for $24 \mathrm{~h}$ at these concentrations, thereby proving the fact that chemopreventive 
$0 \mathrm{~h}$

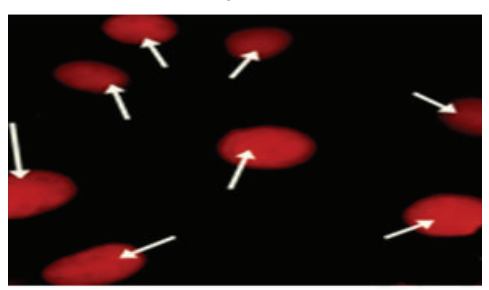

$0 \mathrm{~h}$

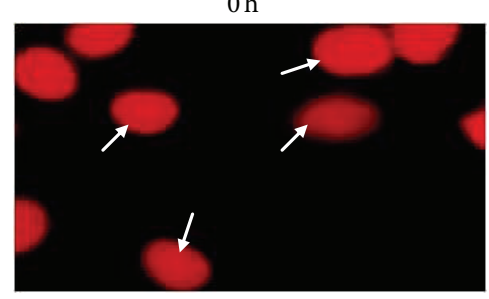

$48 \mathrm{~h}$

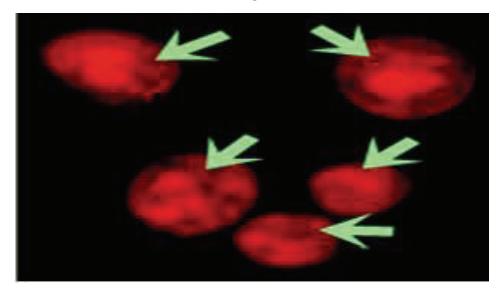

(a)
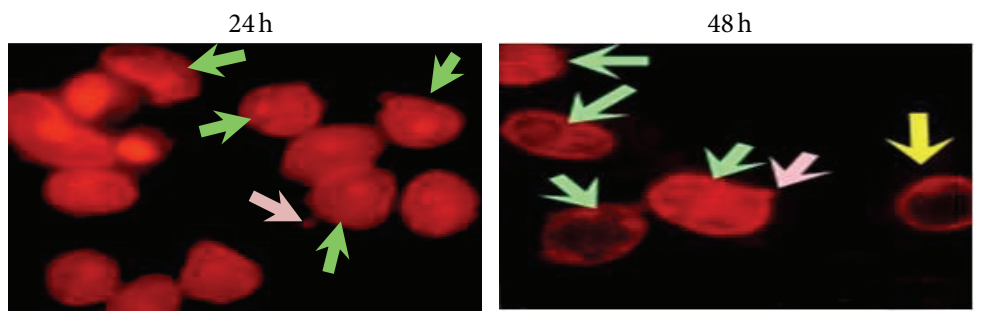

$72 \mathrm{~h}$

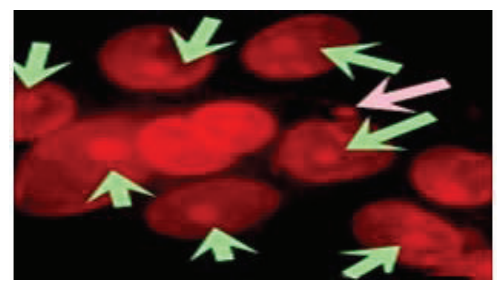

$48 \mathrm{~h}$

(b)

Figure 3: The nuclear morphological changes induced by ENLE treatment at various time intervals on (a) MCF-7 (for 0 , 48, and $72 \mathrm{~h}$ ) and (b) HeLa (for 0, 24, and $48 \mathrm{~h}$ ) cells. Untreated MCF-7 and HeLa cells $(0 \mathrm{~h})$ showed large and prominent nuclei, indicating no significant characteristics of apoptosis (white arrows). On the other hand, ENLE treatment of these cells at their respective EC $_{50}$ induced time-dependent increase in nuclear morphological changes characteristic of apoptotic cells such as nuclear condensation and fragmentation (green arrows), nuclear marginalization (yellow arrows), and appearance of apoptotic bodies (pink arrows) (magnification 400x).

agents like neem can specially target the cancer cells (Figure 1(c)). This property of neem can be utilized for the purpose of cancer treatment because of its safety profile.

\subsection{ENLE Induces Cell Death via Apoptosis in MCF-7 and HeLa Cells}

4.2.1. Morphological Changes Induced by ENLE on MCF-7 and HeLa Cells. ENLE-treated MCF-7 (for 48 and $72 \mathrm{~h}$ ) and $\mathrm{HeLa}$ (for 24 and $48 \mathrm{~h}$ ) cells at the concentrations 50, 200, and $500 \mu \mathrm{g} / \mathrm{mL}$ were observed under an inverted microscope and their morphological characteristics were noted. In comparison to untreated cells, ENLE-treated cells showed typical features of cell death at the morphological level such as rounding off of cells, cell shrinkage, and detachment from the substrate which accumulated in a dose- and time-dependent manner, thus indicating that ENLE induces cell death by apoptosis in these cells (Figures 2(a) and 2(b)).

\subsubsection{Nuclear Morphological Changes Induced by ENLE on} MCF-7 and HeLa Cells. ENLE-induced nuclear morphological changes characteristic of typical cell undergoing apoptosis were studied in MCF-7 and HeLa cells at their respective $\mathrm{EC}_{50}$ at various time-points. Untreated MCF-7 and $\mathrm{HeLa}$ cells appeared uniform in chromatin density with an intact nucleus. However, treatment of MCF-7 cells with ENLE for 48 and $72 \mathrm{~h}$ resulted in apoptosis-associated nuclear morphological changes like chromatin condensation and fragmentation along with appearance of apoptotic bodies (Figure 3(a)). Also, HeLa cells treated with ENLE showed similar changes in addition to chromatin marginalization (Figure 3(b)). With an increase in duration of ENLE exposure, there was a cumulative accrual of the said features consistent with apoptosis in both of the cell lines (Figures 3(a) and 3(b)).

4.2.3. Effect of ENLE on the Cell Cycle Distribution. The effect of ENLE treatment on the cell cycle distribution of MCF7 and HeLa cells was determined by flow cytometry after treatment of these cells with ENLE at their respective $\mathrm{EC}_{50}$ concentrations for 48 and $72 \mathrm{~h}$ for MCF-7 and, 24 and $48 \mathrm{~h}$ for HeLa cells. The untreated cells $(0 \mathrm{~h})$ showed appropriate distribution of cells in the different phases of cell cycle (Figure 4), while in the case of ENLE-treated cells, there was a significant time-dependent increase in the number of cells in the sub- $\mathrm{G}_{0}$ phase of the cell cycle (17 and $30 \%$ for MCF7 after 48 and $72 \mathrm{~h}$ and 15 and 29\% for HeLa after 24 and $48 \mathrm{~h}$ treatment) (Figure 4). This confirms that ENLE induces apoptotic cell death in these cells.

4.3. ENLE Treatment Significantly Modulates the Expression of Bax, Cyclin D1, CYP 1A1, and CYP 1A2. With the target of determining the effector genes involved in ENLE-mediated cellular responses in MCF-7 and HeLa cells, the expression of Bax, cyclin D1, CYP 1A1, and CYP 1A2 was analyzed before and after treatment with ENLE (48 and $72 \mathrm{~h}$ treatment for MCF-7 cells and 24 and $48 \mathrm{~h}$ treatment for HeLa cells). $\beta$ Actin was used as an internal control for comparison of samples.

The aberrant expression of cyclin D1, a key player in the progression of the cells from $\mathrm{G} 1$ to $\mathrm{S}$ phase, has been associated with the deregulated cell cycle control in many human cancers. It was found to be overexpressed in both the untreated MCF-7 and HeLa cells (Figures 5(a) and 5(b)). As 


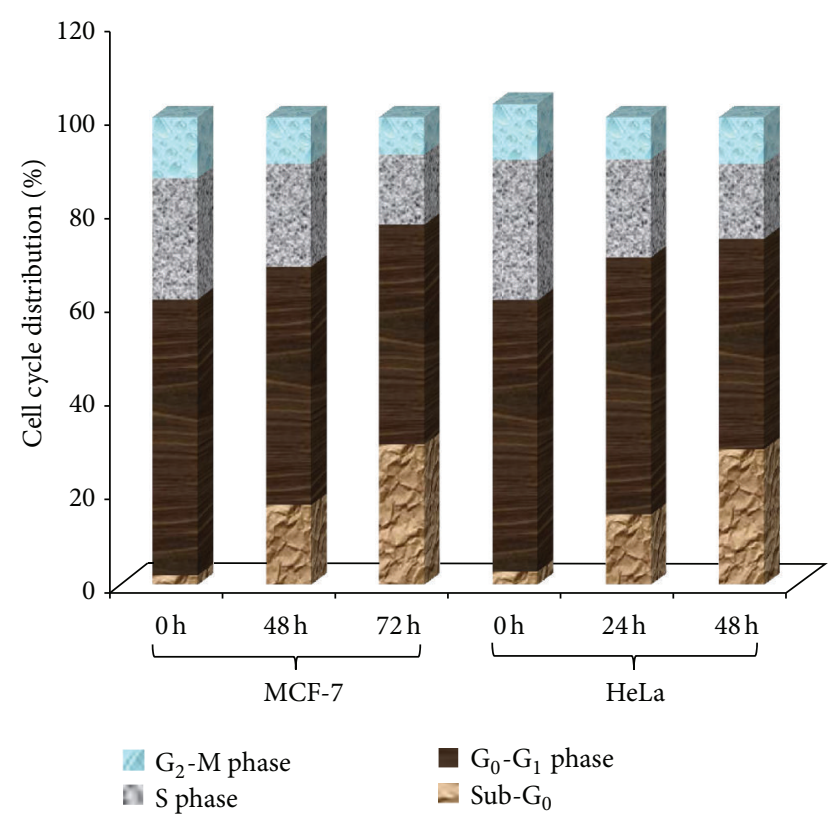

FIgUre 4: ENLE induces apoptosis in MCF-7 and HeLa cells as analyzed by flow cytometry. Untreated MCF-7 and HeLa cells showed normal distribution of cells in various phases of cell cycle, whereas when treated with ENLE at their respective $\mathrm{EC}_{50}$ doses, there was a significant increase in the number of cells in the sub$\mathrm{G}_{0}$ phase of the cell cycle with increasing time of treatment (48 and $72 \mathrm{~h}$ for MCF-7 and 24 and $48 \mathrm{~h}$ for HeLa cells). The histogram shows $\%$ analysis of cells in the different phases of the cell cycle from a representative experiment (out of three individual experiments).

shown in Figures 5(a) and 5(b), a significant, time-dependent inhibitory effect of ENLE was observed on the expression of cyclin D1 in both of the cell lines compared to untreated cells.

Bax, the first identified proapoptotic member of the Bcl2 protein family, plays a major role in inducing apoptosis. In both untreated MCF-7 and HeLa cells, the expression of Bax was found to be low which significantly increased in ENLEtreated MCF-7 and HeLa cells in a time-dependent manner in comparison to the untreated cells (Figures 5(a) and 5(b)).

CYP 1A1 and CYP 1A2 are the members of the cytochrome $\mathrm{P} 450$ enzyme superfamily which act as drug metabolizing enzymes and lead to the accumulation reactive oxygen species forming ultimate carcinogens that are toxic to the cell and thereby leading to tumorigenesis. Expression of CYP $1 \mathrm{~A} 1$ and CYP $1 \mathrm{~A} 2$ was detected in untreated MCF-7 and HeLa cells (Figures 5(a) and 5(b)). However, in comparison to the untreated cells, ENLE treatment resulted in significant downregulation of these genes in both cancer cell lines (Figures 5(a) and 5(b)).

4.4. ENLE and Cisplatin Infusion Act Synergistically to Inhibit the Growth of MCF-7 and HeLa Cells. Since currently available chemotherapeutic drugs are associated with nonspecific cytotoxicity towards normal cells as well as development of chemoresistance, a combinational treatment with the natural dietary agents may serve as a better approach towards cancer treatment. In the present study, a combination of ENLE and cisplatin was evaluated to potentiate the chemotherapeutic index of cisplatin.

The effect of concurrent treatment of MCF-7 and HeLa cells with different sub-lethal concentrations of cisplatin and ENLE for 48 and $24 \mathrm{~h}$, respectively, was analyzed by cell viability assay. It was observed that $1 \mu \mathrm{M}$ of cisplatin (C1) used in combination with $50(\mathrm{~N} 1)$ and $100 \mu \mathrm{g} / \mathrm{mL}$ (N2) ENLE resulted in a significant decrease in cell viability (82 and $71 \%$, resp.) of MCF-7 cells as compared to either of the compounds alone (93.1\% for $\mathrm{Cl}$ and 96 and $85 \%$ for $\mathrm{N} 1$ and N2) (Figure 6(a)). In HeLa cells, the combination of $1 \mu \mathrm{M}$ of cisplatin $(\mathrm{Cl})$ with $10(\mathrm{~N} 3)$ and $50 \mu \mathrm{g} / \mathrm{mL}(\mathrm{N} 4)$ resulted in 61.7 and $60 \%$ (for $\mathrm{C} 1 \mathrm{~N} 3$ and $\mathrm{C} 1 \mathrm{~N} 4$ ) significant decrease in cell viability while individual drugs decreased the cell viability by $94.1 \%$ for $\mathrm{C} 1$ and 84 and $77.3 \%$ with N3 and N4, respectively (Figure 6(b)). Also, treatment of MCF-7 and HeLa cells with $5 \mu \mathrm{M}$ of cisplatin (C2) combined with $\mathrm{N} 1$ and N2 and N3 and N4, respectively, resulted in synergistic decrease in cell viability (73 and $65 \%$ for MCF-7; 51.0 and $52.2 \%$ for HeLa) as compared to individual doses ( $\mathrm{C} 2=87.7 \%$ and $81.8 \%$ for MCF-7 and HeLa) (Figures 6(a) and 6(b)). Combinational indices (CI) were calculated and CI were found to be less than 1 indicating a synergistic interaction between the two drugs at the doses used for both MCF-7 and HeLa cells.

\section{Discussion}

Regardless of recent advances in the prevention and detection of cancer and development of newer treatment modalities, cancer still as remains one of the most dreadful diseases due to the limitations of available treatment strategies $[29,30]$. Research is under way to identify pharmacologically safe chemopreventive agents that can suppress the carcinogenesis process at various stages along with enhancing the therapeutic effects of conventional cancer therapy by tapping the potential of combinational approaches utilizing one or more synthetic or natural phytochemicals along with an effective drug such as chemotherapy $[18,23,31,32]$.

The present study focused on the antiproliferative properties of neem as a biosafe chemopreventive agent. It was found that treatment of MCF-7 and HeLa cells with ethanolic neem leaf extract (ENLE) inhibited the growth of these cells in a dose- and time-dependent manner (Figures 1(a) and 1(b)). The $\mathrm{EC}_{50}$ (effective concentration, the dose which reduces the viability of cells by 50\%) of ENLE was found to be $350 \mu \mathrm{g} / \mathrm{mL}$ on MCF-7 cells and $175 \mu \mathrm{g} / \mathrm{mL}$ on HeLa cells after 72 and $48 \mathrm{~h}$ treatment, respectively. Notably, there was no significant effect of ENLE on the viability of lymphocytes pointing to its selective cytotoxicity towards the cancer cells and, thus, it provides a rationale for development of neem as a biosafe chemopreventive agent (Figure 1(c)). These results are in line with other studies which also showed that neem and its derivatives inhibit growth of various cancer cells such as prostate cancer, leukemia cells, head-and-neck squamous cell carcinoma cells, human choriocarcinoma cells, murine Ehrlich's carcinoma (EC), melanoma cells and exhibited only weak or no cytotoxic effect on normal cells [33-38].

Since carcinogenesis is associated with imbalances in the antiapoptotic and proapoptotic mechanisms leading to 


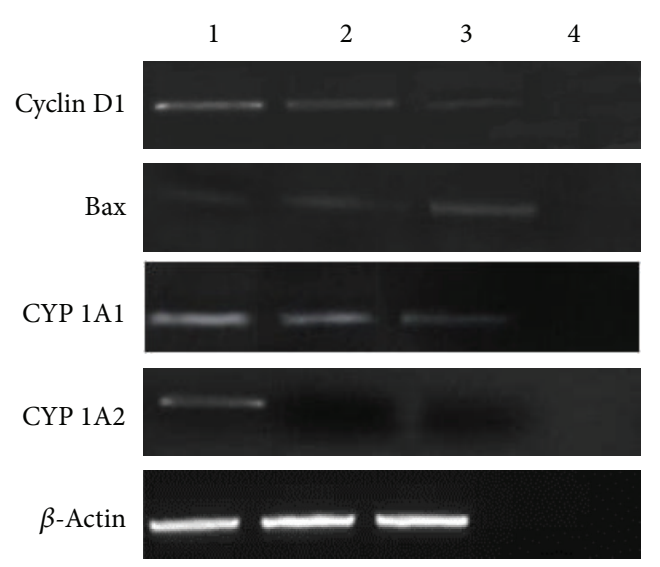

(a)

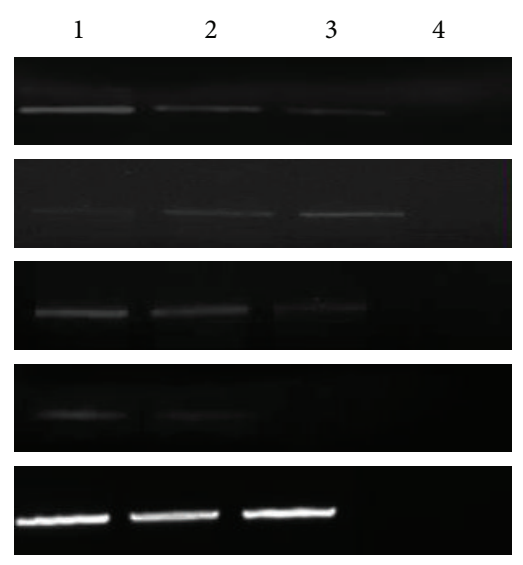

(b)

Figure 5: ENLE-treated MCF-7 (a) and HeLa (b) cells at their respective EC $_{50}$ doses ( $48 \mathrm{~h}$ and $72 \mathrm{~h}$ for MCF-7 cells and, 24 and $48 \mathrm{~h}$ for HeLa cells) show a significant decrease in the expression of cyclin D1, CYP 1A1, and CYP 1A2 but a significant upregulation in the expression of bax in a time-dependent manner compared to untreated cells. $\beta$-Actin was used as an internal control. Lanes 1-4 represent untreated cells, cells treated with ENLE at their particular time of treatments, and negative control for RT-PCR, respectively.

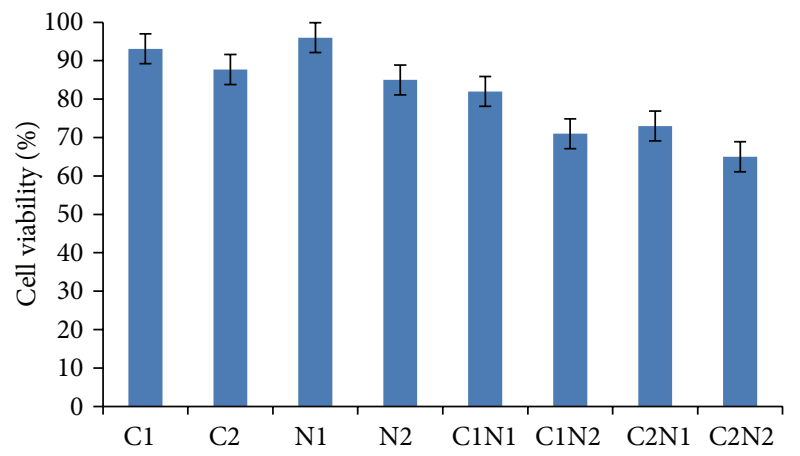

(a)

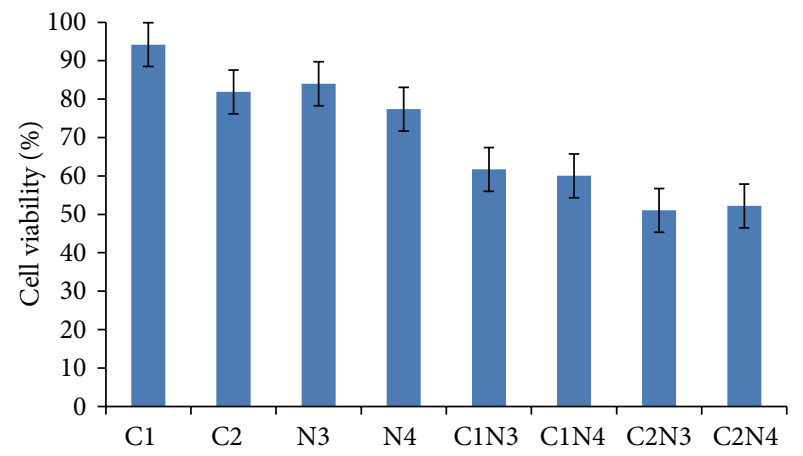

(b)

Figure 6: Simultaneous treatment of MCF-7 (a) and HeLa cells (b) with sublethal doses of cisplatin (C1 and C2) and ENLE (N1 and N2 for MCF-7 and N3 and N4 for HeLa) was found to induce synergistic decrease in viability of these cells (combination index (CI $<1)$ ). Each value is a ratio of the level in the treated cells to that in the untreated control cells. Values are means \pm SD of 3 independent experiments. Each value with cisplatin and ENLE treatment differs from the control value $(P<0.05)$.

rapid and uncontrolled proliferation of cancer cells, therefore, inducing cell death is an important aspect in cancer prevention and therapy [39-41]. For this reason, the mode of cell death induced by ENLE in MCF-7 and HeLa cells was analyzed by changes in the cellular and nuclear morphology. MCF-7 and HeLa cells treated with various concentrations $(50,200$, and $500 \mu \mathrm{g} / \mathrm{mL})$ of ENLE for 48 and $72 \mathrm{~h}$ and 24 and $48 \mathrm{~h}$, respectively, were examined microscopically. ENLEtreated cells showed distinct features such as rounding off, cell shrinkage, and detachment from the matrix, which are the typical characteristics of cells undergoing programmed cell death (apoptosis) compared to untreated cells in which these morphological changes were absent (Figures 2(a) and 2(b)). Also, ENLE-treated MCF-7 and HeLa cells (at EC 50 doses) showed discernible variations in the nuclear morphology of these cells, namely, formation of apoptotic bodies, nuclear condensation, fragmentation, and marginalization in comparison to uniform and intact nuclei of untreated cells (Figures 3(a) and 3(b)). These changes which are the hallmarks of apoptosis accumulated in the ENLE-treated cells in a time-dependent manner (Figures 3(a) and 3(b)).

Further, these results were verified by cell cycle analysis of MCF-7 and HeLa cells with or without ENLE treatment. Treatment of these cells at their respective $\mathrm{EC}_{50}$ concentrations for 48 and $72 \mathrm{~h}$ (MCF-7) and 24 and $48 \mathrm{~h}$ (HeLa) correspondingly resulted in increased proportion of cells in the sub- $G_{0}$ phase of the cell cycle in a time-dependent manner compared to the untreated cells (Figure 4). These results conclusively prove that ENLE induces cell death in these cells mediated by the apoptotic pathway which are in agreement with previous studies that demonstrated apoptosis induction through various mechanisms such as inhibiting $\mathrm{PI} 3 \mathrm{~K} / \mathrm{Akt}$ pathway, decrease in $\mathrm{Bcl}-2 / \mathrm{Bax}$ ratio with increased expression of Apaf-1 and caspase-3, and cleavage of poly (ADP-ribose) polymerase was the mode of cell death induced by neem or its derivatives such as nimbolide in 
various cancers $[6,11,14-16,35-37,42]$. Thus, the activation of apoptosis is believed to be a critical therapeutic target for chemoprevention-based therapies.

ENLE-induced anticancer effects were then correlated with the modulation of gene expression of various effector molecules involved in cell cycle regulation, apoptosis, and drug metabolism. Cyclin D1, an important cell cycle regulator, is frequently overexpressed in several human cancers including breast and cervical $[43,44]$. It was observed that untreated MCF-7 and HeLa cells showed a high expression of cyclin D1, which was significantly downregulated in a timedependent manner in ENLE-treated cells (Figures 5(a) and 5(b)). These results are consistent with previous studies in which the antiproliferative action of neem and its bioactive components was associated with the downregulation of cyclin D1 expression in cancer cells $[15,16,37]$.

Apoptosis is tightly regulated by a number of gene products that promote or block cell death at different stages. Bax, a proapoptotic gene, commits the cell to undergo programmed cell death in response to a wide range of cytotoxic stimuli [45]. The untreated MCF-7 and HeLa cells showed low expression of Bax (Figures 5(a) and 5(b)). However, on treatment of these cells with ENLE at their respective $\mathrm{EC}_{50}$ doses, there was a significant increase in the Bax gene expression in a timedependent manner, accounting for the apoptosis-inducing activity of ENLE (Figures 5(a) and 5(b)). These results are in concordance with previous studies which found that neem and its component nimbolide upregulate Bax expression in human prostrate and colon cancer cells thus proving the potential of ENLE to induce apoptosis at the molecular level $[36,37,46,47]$.

CYP 1A1 and CYP 1A2, members of cytochrome P450 enzyme superfamily, are involved in the oxidative metabolism of endogenous compounds, such as steroids and fatty acids, and in the metabolism of foreign chemicals such as drugs, carcinogens, and other environmental pollutants. Increases in their expression have been linked to a higher risk of malignancies [48]. This is the first study in which the effect of ENLE on modulation of expression of CYP 1A1 and CYP 1A2 was analyzed. ENLE treatment resulted in significant decrease in their expression in a time-dependent manner as compared to untreated cells which showed relatively higher expression of these genes. This indicates neem can prevent or revert carcinogen induced accumulation of reactive oxygen metabolites which play a pivotal role in carcinogenesis [49]. Other studies have shown similar results in which quercetin, azadirachtin, and nimbolide exhibited free radical scavenging activity by downregulation of CYP $1 \mathrm{~A} 1$ and 1A2 [5054]. CYPs have also been correlated with bioactivation or inactivation of both carcinogens and anticancer drugs and thus modulation of their expression may be key determinants of cancer therapy $[55,56]$.

Conventional cancer treatments such as chemotherapy are associated with several cytotoxic effects; hence it was postulated that these drugs, when combined at lower dose with chemopreventive agents such as neem, can minimize the cytotoxicity while potentiating the therapeutic index [57]. It was found that cisplatin had nonspecific cytotoxicity towards both of the cancer cell lines (MCF-7 and HeLa cells) along with the normal cells (data not shown).

In context of the above mentioned facts, this is the first report analyzing the combined effect of ENLE and cisplatin on MCF-7 and HeLa cells. It was observed that sublethal doses of ENLE and cisplatin in various combinations (C1N1, C1N2, C2N1, and C2N2 for MCF-7 and C1N3, C1N4, $\mathrm{C} 2 \mathrm{~N} 3$ and $\mathrm{C} 2 \mathrm{~N} 4$ for HeLa cells) showed enhanced growth inhibitory effects in comparison to the individual doses as reflected in the CI less than 1 indicating a synergistic interaction between these drugs at the doses used (Figures 6(a) and 6(b)). Veeraraghavan and coworkers (2011) have also shown that neem induced radiosensitization radiotherapy [19]. Also, neem leaf preparation (NLP) has been shown to prevent the cyclophosphamide, cisplatin, and 5-fluorouracilinduced hematological complications $[14,18]$. Therefore, combinations of chemopreventive agents with chemotherapeutic drugs may have immense prospects for development of therapeutic strategies to overcome chemotherapy associated resistance and side-effects in human cancers by synergistic crosstalk between two probable therapies.

\section{Conclusion}

It can be inferred from the present study that neem alone or its infusion with cisplatin exhibits antineoplastic effects in breast and cervical cancers by inducing apoptosis and modulation of expression of effector molecules. Thereby, this study provides a rationale for extensive research and development work on neem for its better therapeutic utilization in cancer prevention and treatment.

\section{Conflict of Interests}

The authors declare that there is no conflict of interests regarding the publication of this paper.

\section{Acknowledgments}

The authors are grateful to Dr. Kota Reddy, Academic President, and Dr. Firdos Alam Khan, Chairperson, Department of Biotechnology, Manipal University, Dubai, for their constant support and encouragement.

\section{References}

[1] K. Biswas, I. Chattopadhyay, R. K. Banerjee, and U. Bandyopadhyay, "Biological activities and medicinal properties of neem (Azadirachta indica)," Current Science, vol. 82, no. 11, pp. 13361345, 2002.

[2] U. Bandyopadhyay, K. Biswas, A. Sengupta et al., "Clinical studies on the effect of Neem (Azadirachta indica) bark extract on gastric secretion and gastroduodenal ulcer," Life Sciences, vol. 75, no. 24, pp. 2867-2878, 2004.

[3] B. Sultana, F. Anwar, and R. Przybylski, "Antioxidant activity of phenolic components present in barks of Azadirachta indica, Terminalia arjuna, Acacia nilotica, and Eugenia jambolana Lam. trees," Food Chemistry, vol. 104, no. 3, pp. 1106-1114, 2007.

[4] P. E. Ebong, I. J. Atangwho, E. U. Eyong, and G. E. Egbung, "The antidiabetic efficacy of combined extracts from two continental 
plants: Azadirachta indica (A. Juss) (Neem) and Vernonia amygdalina (Del.) (African Bitter Leaf)," The American Journal of Biochemistry and Biotechnology, vol. 4, no. 3, pp. 239-244, 2008.

[5] S. Mahapatra, C. Y. F. Young, M. Kohli et al., "Antiangiogenic effects and therapeutic targets of Azadirachta indica leaf extract in endothelial cells," Evidence-Based Complementary and Alternative Medicine, vol. 2012, Article ID 303019, 14 pages, 2012.

[6] R. Paul, M. Prasad, and N. K. Sah, "Anticancer biology of Azadirachta indica L (neem): a mini review," Cancer Biology and Therapy, vol. 12, no. 6, pp. 467-476, 2011.

[7] P. Manikandan, P. V. Letchoumy, M. Gopalakrishnan, and S. Nagini, "Evaluation of Azadirachta indica leaf fractions for in vitro antioxidant potential and in vivo modulation of biomarkers of chemoprevention in the hamster buccal pouch carcinogenesis model," Food and Chemical Toxicology, vol. 46, no. 7, pp. 2332-2343, 2008.

[8] W. R. Kusamran, A. Ratanavila, and A. Tepsuwan, "Effects of neem flowers, Thai and Chinese bitter gourd fruits and sweet basil leaves on hepatic monooxygenases and glutathione S-transferase activities, and in vitro metabolic activation of chemical carcinogens in rats," Food and Chemical Toxicology, vol. 36, no. 6, pp. 475-484, 1998.

[9] S. Balasenthil, S. Arivazhagan, C. R. Ramachandran, V. Ramachandran, and S. Nagini, "Chemopreventive potential of neem (Azadirachta indica) on 7,12-dimethylbenz[a] anthracene (DMBA) induced hamster buccal pouch carcinogenesis," Journal of Ethnopharmacology, vol. 67, no. 2, pp. 189-195, 1999.

[10] A. Tepsuwan, P. Kupradinun, and W. R. Kusamran, "Chemopreventive potential of neem flowers on carcinogen-induced rat mammary and liver carcinogenesis," Asian Pacific Journal of Cancer Prevention, vol. 3, no. 3, pp. 231-238, 2002.

[11] J. Arakaki, M. Suzui, T. Morioka et al., "Antioxidative and modifying effects of a tropical plant Azadirachta indica (Neem) on azoxymethane-induced preneoplastic lesions in the rat colon," Asian Pacific journal of Cancer Prevention, vol. 7, no. 3, pp. 467-471, 2006.

[12] M. Schumacher, C. Cerella, S. Reuter, M. Dicato, and M. Diederich, "Anti-inflammatory, pro-apoptotic, and anti-proliferative effects of a methanolic neem (Azadirachta indica) leaf extract are mediated via modulation of the nuclear factor- $\kappa \mathrm{B}$ pathway," Genes and Nutrition, vol. 6, no. 2, pp. 149-160, 2011.

[13] S. M. Vasenwala, R. Seth, N. Haider et al., "A study on antioxidant and apoptotic effect of Azadirachta indica (neem) in cases of cervical cancer," Archives of Gynecology and Obstetrics, vol. 286, no. 5, pp. 1255-1259, 2012.

[14] D. Ghosh, A. Bose, E. Haque, and R. Baral, "Pretreatment with neem (Azadirachta indica) leaf preparation in Swiss mice diminishes leukopenia and enhances the antitumor activity of cyclophosphamide," Phytotherapy Research, vol. 20, no. 9, pp. 814-818, 2006.

[15] G. H. Kumar, R. Vidya Priyadarsini, G. Vinothini, P. Vidjaya Letchoumy, and S. Nagini, "The neem limonoids azadirachtin and nimbolide inhibit cell proliferation and induce apoptosis in an animal model of oral oncogenesis," Investigational New Drugs, vol. 28, no. 4, pp. 392-401, 2010.

[16] R. V. Priyadarsini, R. S. Murugan, P. Sripriya, D. Karunagaran, and S. Nagini, "The neem limonoids azadirachtin and nimbolide induce cell cycle arrest and mitochondria-mediated apoptosis in human cervical cancer (HeLa) cells," Free Radical Research, vol. 44, no. 6, pp. 624-634, 2010.
[17] D. Ghosh, A. Bose, E. Haque, and R. Baral, "Neem (Azadirachta indica) leaf preparation prevents leukocyte apoptosis mediated by cisplatin plus 5-fluorouracil treatment in swiss mice," Chemotherapy, vol. 55, no. 3, pp. 137-144, 2009.

[18] D. Ezz-Din, M. S. Gabry, A. R. H. Farrag, and A. E. Abdel Moneim, "Physiological and histological impact of Azadirachta indica (neem) leaves extract in a rat model of cisplatin-induced hepato and nephrotoxicity," Journal of Medicinal Plant Research, vol. 5, no. 23, pp. 5499-5506, 2011.

[19] J. Veeraraghavan, S. Aravindan, M. Natarajan, V. Awasthi, T. S. Herman, and N. Aravindan, "Neem leaf extract induces radiosensitization in human neuroblastoma xenograft through modulation of apoptotic pathway," Anticancer Research, vol. 31, no. 1, pp. 161-170, 2011.

[20] T. Kpela, T. B. Ekanem, and A. O. Akpantah, "Protective effect of ethanol extract of neem leaves on cisplatin-induced kidney damage in wistar rats," Journal of Medical Sciences, vol. 1, no. 9, pp. 249-254, 2012

[21] W. S. Tsai, W.-S. Yeow, A. Chua et al., "Enhancement of Apo2L/ TRAIL-mediated cytotoxicity in esophageal cancer cells by cisplatin," Molecular Cancer Therapeutics, vol. 5, no. 12, pp. 2977-2990, 2006.

[22] Y. Wang, L. Chen, G. Huang et al., "Klotho sensitizes human lung cancer cell line to cisplatin via PI3k/Akt pathway," PLoS ONE, vol. 8, no. 2, Article ID e57391, 2013.

[23] A. Hussain, G. Harish, S. A. Prabhu et al., "Inhibitory effect of genistein on the invasive potential of human cervical cancer cells via modulation of matrix metalloproteinase- 9 and tissue inhibitors of matrix metalloproteinase-1 expression," Cancer Epidemiology, vol. 36, no. 6, pp. 387-393, 2012.

[24] R. Subapriya, V. Bhuvaneswari, and S. Nagini, "Ethanolic neem (Azadirachta indica) leaf extract induces apoptosis in the hamster buccal pouch carcinogenesis model by modulation of Bcl-2, Bim, caspase 8 and caspase 3," Asian Pacific Journal of Cancer Prevention, vol. 6, no. 4, pp. 515-520, 2005.

[25] M. Tatemichi, S. Nomura, T. Ogura, H. Sone, H. Nagata, and H. Esumi, "Mutagenic activation of environmental carcinogens by microsomes of gastric mucosa with intestinal metaplasia," Cancer Research, vol. 59, no. 16, pp. 3893-3898, 1999.

[26] J. P. Alao, E. W.-F. Lam, S. Ali et al., "Histone deacetylase inhibitor trichostatin A represses estrogen receptor $\alpha$ dependent transcription and promotes proteasomal degradation of cyclin D1 in human breast carcinoma cell lines," Clinical Cancer Research, vol. 10, no. 23, pp. 8094-8104, 2004.

[27] A.-G. Wang, S.-U. Kim, S. H. Lee et al., "Histone deacetylase 1 contributes to cell cycle and apoptosis," Biological and Pharmaceutical Bulletin, vol. 28, no. 10, pp. 1966-1970, 2005.

[28] M. Nishimura, A. Koeda, Y. Suganuma et al., "Comparison of inducibility of CYP1A and CYP3A mRNAs by prototypical inducers in primary cultures of human, cynomolgus monkey, and rat hepatocytes," Drug Metabolism and Pharmacokinetics, vol. 22, no. 3, pp. 178-186, 2007.

[29] H. Nersesyan and K. V. Slavin, "Current aproach to cancer pain management: availability and implications of different treatment options," Therapeutics and Clinical Risk Management, vol. 3, no. 3, pp. 381-400, 2007.

[30] S. Verma, S. Sehdev, and A. A. Joy, "Cancer therapy disparity: unequal access to breast cancer therapeutics and drug funding in Canada," Current Oncology, vol. 14, supplement 1, pp. S3-S10, 2007. 
[31] D. Ghosh, A. Bose, E. Haque, and R. Baral, "Neem (Azadirachta indica) leaf preparation prevents leukocyte apoptosis mediated by cisplatin plus 5-fluorouracil treatment in swiss mice," Chemotherapy, vol. 55, no. 3, pp. 137-144, 2009.

[32] M. A. Macha, A. Matta, S. S. Chauhan, K. W. Michael Siu, and R. Ralhan, "Guggulsterone (GS) inhibits smokeless tobacco and nicotine-induced NF- $\kappa$ B and STAT3 pathways in head and neck cancer cells," Carcinogenesis, vol. 32, no. 3, pp. 368-380, 2011.

[33] U. Bandyopadhyay, K. Biswas, R. Chatterjee et al., "Gastroprotective effect of Neem (Azadirachta indica) bark extract: possible involvement of $\mathrm{H}^{+}$- $\mathrm{K}^{+}$-ATPase inhibition and scavenging of hydroxyl radical," Life Sciences, vol. 71, no. 24, pp. 2845-2865, 2002.

[34] E. Haque, I. Mandal, S. Pal, and R. Baral, "Prophylactic dose of neem (Azadirachta indica) leaf preparation restricting murine tumor growth is nontoxic, hematostimulatory and immunostimulatory," Immunopharmacology and Immunotoxicology, vol. 28, no. 1, pp. 33-50, 2006.

[35] A. Bose, E. Haque, and R. Baral, "Neem leaf preparation induces apoptosis of tumor cells by releasing cytotoxic cytokines from human peripheral blood mononuclear cells," Phytotherapy Research, vol. 21, no. 10, pp. 914-920, 2007.

[36] G. Harish Kumar, K. V. P. Chandra Mohan, A. Jagannadha Rao, and S. Nagini, "Nimbolide a limonoid from Azadirachta indica inhibits proliferation and induces apoptosis of human choriocarcinoma (BeWo) cells," Investigational New Drugs, vol. 27, no. 3, pp. 246-252, 2009.

[37] D. N. Gunadharini, P. Elumalai, R. Arunkumar, K. Senthilkumar, and J. Arunakaran, "Induction of apoptosis and inhibition of PI3K/Akt pathway in PC-3 and LNCaP prostate cancer cells by ethanolic neem leaf extract," Journal of Ethnopharmacology, vol. 134, no. 3, pp. 644-650, 2011.

[38] T. Kikuchi, K. Ishii, T. Noto et al., "Cytotoxic and apoptosisinducing activities of limonoids from the seeds of Azadirachta indica (Neem)," Journal of Natural Products, vol. 74, no. 4, pp. 866-870, 2011.

[39] P.-A. Clavien, H. A. Rüdiger, M. Selzner et al., "Mechanism of hepatocyte death after ischemia: apoptosis versus necrosis," Hepatology, vol. 33, no. 6, pp. 1555-1557, 2001.

[40] P. Vaupel and M. Hockel, "Blood supply, oxygenation status and metabolic micromilieu of breast cancers: characterization and therapeutic relevance," International Journal of Oncology, vol. 17, no. 5, pp. 869-879, 2000.

[41] R. S. Wong, "Apoptosis in cancer: from pathogenesis to treatment," Journal of Experimental and Clinical Cancer Research, vol. 30, article 87, 2011.

[42] K. Kavitha, R. Vidya Priyadarsini, P. Anitha et al., "Nimbolide, a neem limonoid abrogates canonical NF- $\kappa$ B and Wnt signaling to induce caspase-dependent apoptosis in human hepatocarcinoma (HepG2) cells," European Journal of Pharmacology, vol. 681, no. 1-3, pp. 6-14, 2012.

[43] R. L. Sutherland and E. A. Musgrove, "Cyclin D1 and mammary carcinoma: new insights from transgenic mouse models," Breast Cancer Research, vol. 4, no. 1, pp. 14-17, 2002.

[44] H. Biliran Jr., Y. Wang, S. Banerjee et al., "Overexpression of cyclin D1 promotes tumor cell growth and confers resistance to cisplatin-mediated apoptosis in an elastase-myc transgeneexpressing pancreatic tumor cell line," Clinical Cancer Research, vol. 11, no. 16, pp. 6075-6086, 2005.

[45] S. M. Cuddeback, H. Yamaguchi, K. Komatsu et al., "Molecular cloning and characterization of Bif-1. A novel Src homology
3 domain-containing protein that associates with Bax," Journal of Biological Chemistry, vol. 276, no. 23, pp. 20559-20565, 2001.

[46] S. Kumar, P. K. Suresh, M. R. Vijayababu, A. Arunkumar, and J. Arunakaran, "Anticancer effects of ethanolic neem leaf extract on prostate cancer cell line (PC-3)," Journal of Ethnopharmacology, vol. 105, no. 1-2, pp. 246-250, 2006.

[47] P. Elumalai, D. N. Gunadharini, K. Senthilkumar et al., "Ethanolic neem (Azadirachta indica A. Juss) leaf extract induces apoptosis and inhibits the IGF signaling pathway in breast cancer cell lines," Biomedicine and Preventive Nutrition, vol. 2, no. 1, pp. 59-68, 2012.

[48] D. D. Petersen, C. E. McKinney, K. Ikeya et al., "Human CYP1A1 gene: cosegregation of the enzyme inducibility phenotype and an RFLP," The American Journal of Human Genetics, vol. 48, no. 4, pp. 720-725, 1991.

[49] V. P. Androutsopoulos, A. M. Tsatsakis, and D. A. Spandidos, "Cytochrome P450 CYP1A1: wider roles in cancer progression and prevention," BMC Cancer, vol. 9, article 187, 2009.

[50] J. Basiak, A. Trzeciak, A. Gsiorowska, J. Drzewoski, and E. Maecka-Panas, "Vitamin $\mathrm{C}$ and quercetin modulate DNAdamaging effect of $\mathrm{N}$-methyl- $\mathrm{N}^{\prime}$-nitro-N-nitrosoguanidine (MNNG)," Plant Foods for Human Nutrition, vol. 57, no. 1, pp. 53-61, 2002.

[51] J. R. Bacon, G. Williamson, R. C. Garner, G. Lappin, S. Langouët, and Y. Bao, "Sulforaphane and quercetin modulate PhIP-DNA adduct formation in human HepG2 cells and hepatocytes," Carcinogenesis, vol. 24, no. 12, pp. 1903-1911, 2003.

[52] R. V. Priyadarsini, P. Manikandan, G. H. Kumar, and S. Nagini, "The neem limonoids azadirachtin and nimbolide inhibit hamster cheek pouch carcinogenesis by modulating xenobioticmetabolizing enzymes, DNA damage, antioxidants, invasion and angiogenesis," Free Radical Research, vol. 43, no. 5, pp. 492504, 2009.

[53] E. J. Choi, T. Kim, and G. H. Kim, "Quercetin acts as an antioxidant and downregulates CYP1A1 and CYP1B1 against DMBA-induced oxidative stress in mice," Oncology Reports, vol. 28, no. 1, pp. 291-296, 2012.

[54] R. V. Priyadarsini and S. Nagini, "Quercetin suppresses cytochrome $\mathrm{P} 450$ mediated ROS generation and NF $\kappa \mathrm{B}$ activation to inhibit the development of 7,12-dimethylbenz[a] anthracene (DMBA) induced hamster buccal pouch carcinomas," Free Radical Research, vol. 46, no. 1, pp. 41-49, 2012.

[55] T. Oyama, N. Kagawa, N. Kunugita et al., "Expression of cytochrome P450 in tumor tissues and its association with cancer development," Frontiers in Bioscience, vol. 9, pp. 1967-1976, 2004.

[56] K. M. Huttunen, N. Mähönen, H. Raunio, and J. Rautio, "Cytochrome P450-activated prodrugs: targeted drug delivery," Current Medicinal Chemistry, vol. 15, no. 23, pp. 2346-2365, 2008.

[57] N. Pabla and Z. Dong, "Curtailing side effects in chemotherapy: a tale of PKC $\delta$ in cisplatin treatment," Oncotarget, vol. 3, no. 1, pp. 107-111, 2012. 


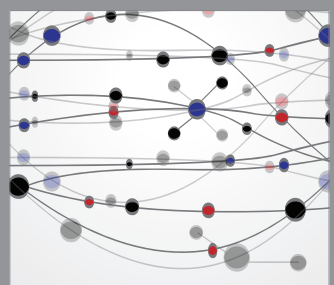

The Scientific World Journal
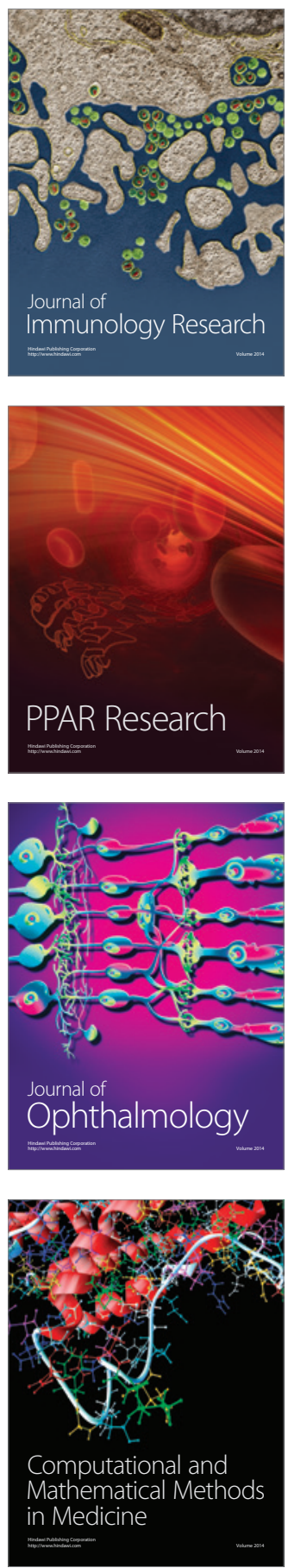

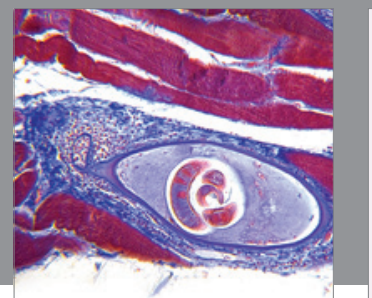

Gastroenterology

Research and Practice
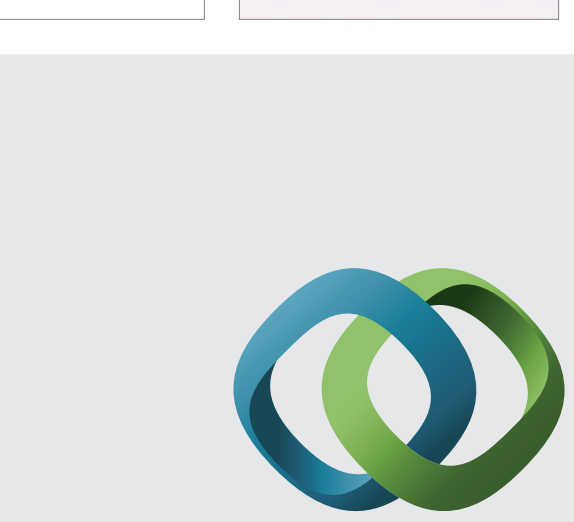

\section{Hindawi}

Submit your manuscripts at

http://www.hindawi.com
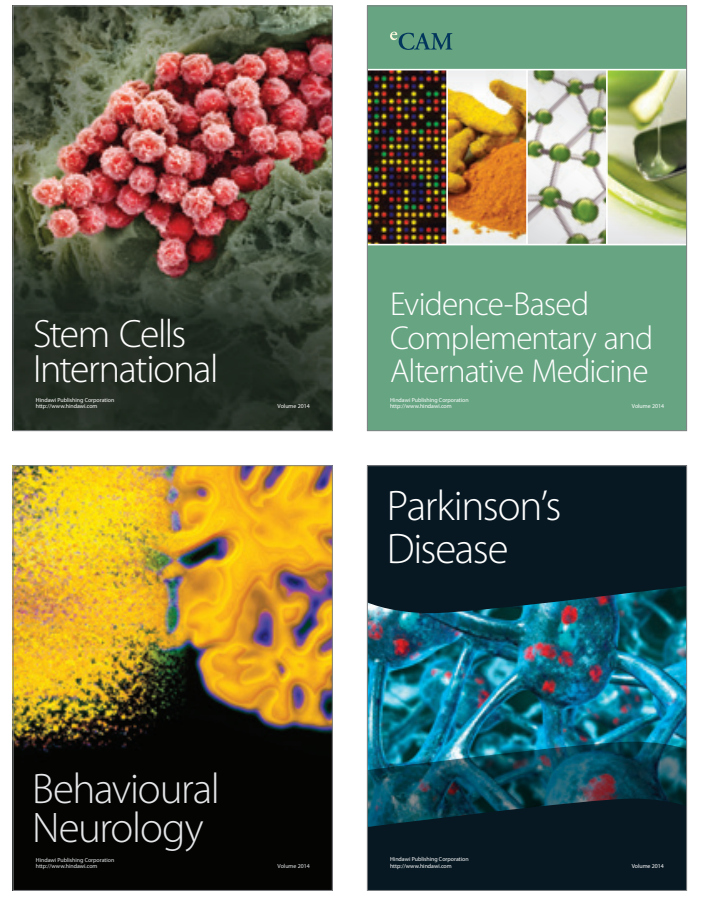
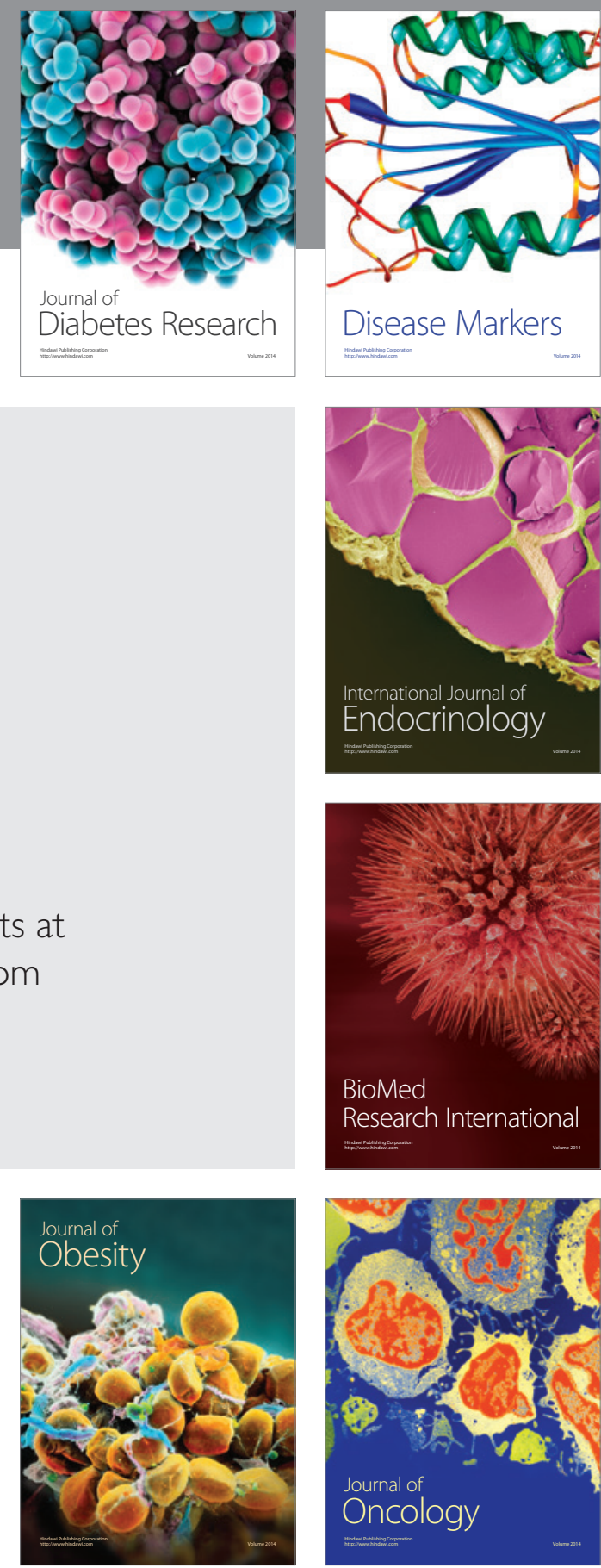

Disease Markers
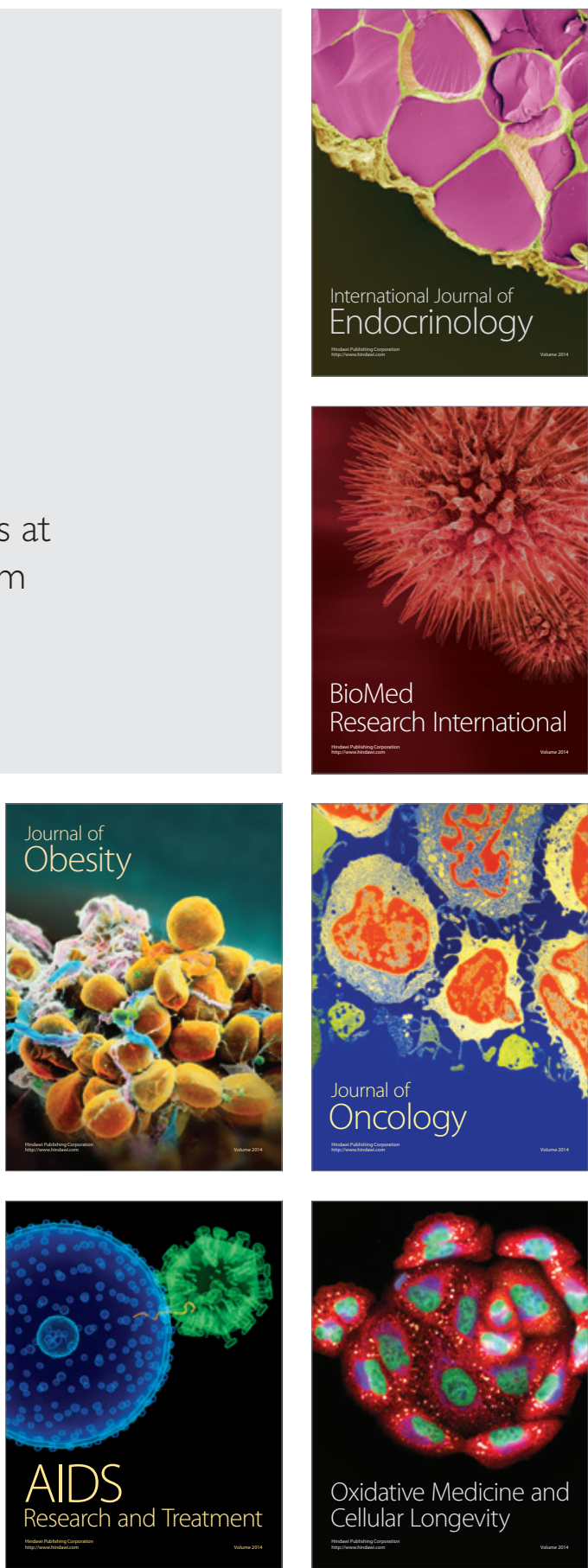